\title{
Comparative analysis of PV powered KY and Luo converter
}

\author{
R.Elavarasu ${ }^{1}$, C.Nayanatara ${ }^{2}$, Suchitra Dayalan ${ }^{3}$, S.Krishnaveni ${ }^{4}{ }^{\text {K. }}$.Ranjitha ${ }^{5}$ \\ ${ }^{1}$ Rajalakshmi Institute of Technology, Chennai, Tamilnadu, India, elava3000@ gmail.com \\ ${ }^{2}$ Sri Sairam Engineering College, Chennai, Tamilnadu, India, nayanathara.eee@ sairam.edu.in \\ ${ }^{3}$ SRM Institute of Science and Technology, Chennai, Tamilnadu, India, such1978@yahoo.com \\ ${ }^{4}$ Dr.M.G.R Educational and Research Institute, Chennai, Tamilnadu, India, krishnaveni.eee@ drmgrdu.ac.in \\ ${ }^{5}$ Rajalakshmi Institute of Technology, Chennai, Tamilnadu, India, ranjitha.k@ ritchennai.edu.in
}

\begin{abstract}
PV power is the one of best alternatives for conventional energy sources. The main drawback of renewable power is not a reliable/constant one. So it requires a suitable converter that will quickly respond depends on the changes in the input supply. There are many types of DC-DC converters are available. These converter output voltages can be changed by varying the duty cycle ratio of the switches present in the converter. The Luo and KY converters are in emerging trends used for the PV energy conversion system. In this paper, the parameters like switching losses, transient response, output voltage, and efficiency are compared with each other. Also, the circuit diagram of Luo and KY converters are simulated using MATLAB/Simulink and the output results of these converters are compared and analyzed.
\end{abstract}

Key words : DC-DC converter, KY converter, Luo converter and Photovoltaic(PV)

\section{INTRODUCTION}

Now a day's most of the world is replacing the conventional sources by renewable energy sources. But the renewable energy output power is very less compared with conventional energy sources. It requires a suitable converter to boost up the voltage and respond depends on the continuous variation in the input side. So it needs more concentration on the converter side to improve the voltage gain and efficiency with fewer harmonics. The renewable energy system requires a high gain boost converter explained and implemented in [1]-[2]. The major demerits are pulsating output current which will affect the output voltage. So overall output efficiency is reduced. In [3], presents the high performance of an integrated KY converter. It describes small output voltage ripples and fast transient response compared with a boost converter. The voltage boosting converter is presented in [4]. In this paper, 1-plus-2D and 2-plus-D converters are explained with the same structure with different PWM techniques. The KY converter provides low output voltage ripples and a very fast transient response. The step-up boost converter is also called a $\mathrm{KY}$ converter [5] which works in transient response in CCM mode, provides low output current ripples, and low output voltage ripple. Also, the output voltage gain is very high. In [6] presents a voltage lift Luo converter which has a simple structure, very low ripple output voltage, and high efficiency. The positive output super lift re lift Luo converter [7] presents regulating the output voltage by feedback signal and its gain is improved. Also, it overcomes the phase obstacle by a DC-DC boost converter. In this paper, the KY and Luo converters are compared and discussed the performances like switching losses and transient response.

\section{CIRCUIT CONFIGURATION}

\subsection{KY Converter}

The KY converter is a step-up DC-DC converter. The transient response operating in CCM is always with low ripple voltage with the non-pulsating current. It consists of two bidirectional switches $\mathrm{S} 1, \mathrm{~S} 2$, one diode $\mathrm{Db}$, one energy transferring capacitor $\mathrm{Cb}$, one inductor $\mathrm{L}$, one output capacitor Co and Load resistor R. The circuit diagram of KY converter is shown in Fig 1.

The operation of the KY converter is divided into two modes. Mode 1: When the switch S1 is ON and switch S2 is OFF condition, the voltage across the inductor $\mathrm{L}$ is equal to inductor voltage (VL) added with capacitor voltage $(\mathrm{Vc})$ minus the output voltage (Vo) thereby causing inductor $\mathrm{L}$ to be magnetized. The capacitor current is equal to the current flowing through the inductor $\mathrm{L}$ minus the current flowing through the load $(\mathrm{Vo} / \mathrm{R})$. In this mode, the capacitor $\mathrm{Cb}$ is discharged. The mode 1 power flow diagram is shown in Fig 2. 
R.Elavarasu et al., International Journal of Emerging Trends in Engineering Research, 8(10), October 2020, 7116 - 7121

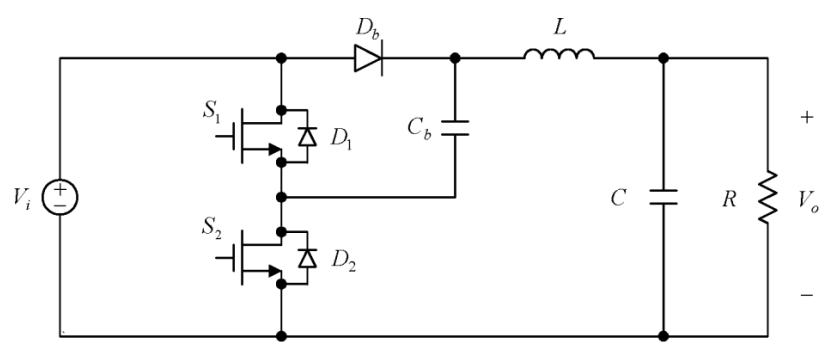

Fig 1. Circuit diagram of KY converter

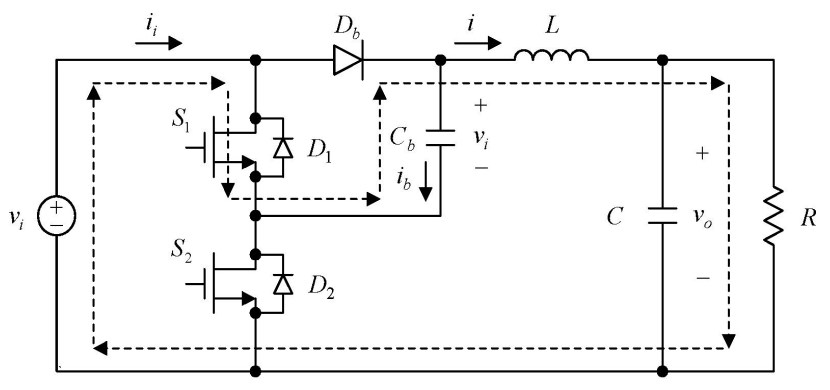

Fig 2. Power flow diagram of KY converter in Mode 1.

Mode 2: When the switch $S_{1}$ is OFF and switch $S_{2}$ is ON condition, the voltage across the inductor $\mathrm{L}$ is equal to the input voltage $(\mathrm{Vi})$ minus the output voltage (Vo) thereby causing inductor $\mathrm{L}$ to be demagnetized. The capacitor current is equal to the current flowing through the inductor $\mathrm{L}$ minus the current flowing through the load (Vo/R). In this mode, the capacitor $\mathrm{C}_{\mathrm{b}}$ is abruptly charged to input voltage $\mathrm{Vi}$ with a very short period. The mode 2 power flow diagram is shown in Fig 3.

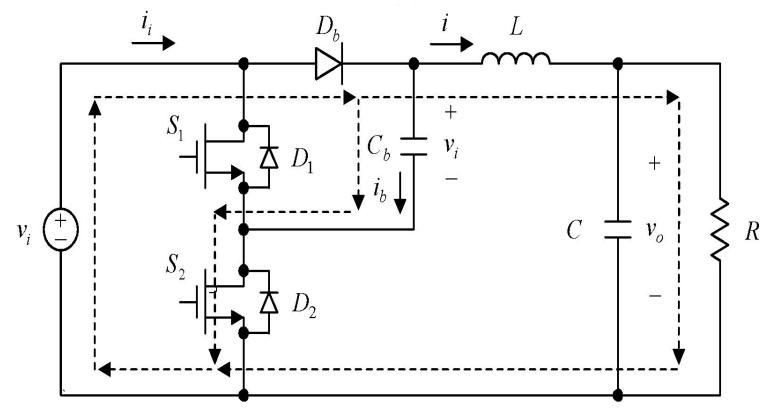

Fig 3. Power flow diagram of KY converter in Mode 2.

The voltage gain is given as

$$
\text { Vout } / \mathrm{Vi} / \mathrm{p}=1+\mathrm{D}
$$

where, D is Duty cycle.
The design specifications of the KY converter are given as follows:

Output current is calculated as

$$
\text { Iout }=\text { Pout } / \text { Vout }
$$

Input current is given as

$$
\mathrm{Ii} / \mathrm{p}=\mathrm{Pi} / \mathrm{p} / \mathrm{Vi} / \mathrm{p}
$$

Voltage gain is calculated as

$$
\text { Gain }=\text { Vout } / \mathrm{Vi} / \mathrm{p}
$$

In mode 1 , the voltage across the inductor is

$$
\mathrm{V}_{\mathrm{L}}=2 \mathrm{Vi} / \mathrm{p}-\text { Vout }
$$

The inductor voltage current basic relation is

$$
\begin{gathered}
\mathrm{V}_{\mathrm{L}}=\mathrm{L} * \mathrm{dI} / \mathrm{dt} \\
\mathrm{L}=\mathrm{V}_{\mathrm{L}} * \mathrm{dt} / \mathrm{dI}
\end{gathered}
$$

Where $\mathrm{dt}=$ duty cycle $/$ frequency

Assume that inductor ripple current $=40 \%$ of inductor current

$$
\mathrm{dI}=40 \% * \mathrm{I}_{\mathrm{L}}
$$

The capacitor voltage current basic relation is

$$
\mathrm{I}=\mathrm{C} * \mathrm{dV} / \mathrm{dt}
$$

Where $\mathrm{dV}$ is output ripple voltage.

Assume that output ripple voltage is about $0.05 \%$ of output voltage

$$
\mathrm{C}=\mathrm{Ii} / \mathrm{p} * \mathrm{dt} / \mathrm{dV}
$$

Where $\mathrm{dt}=$ duty ratio/frequency

$$
\begin{array}{r}
\mathrm{C}=\mathrm{Ii} / \mathrm{p} * \mathrm{D} /(\mathrm{F} * \mathrm{dV}) \\
\mathrm{C}=\mathrm{Iout} * \mathrm{dt} / \mathrm{dV}
\end{array}
$$

Where $\mathrm{dt}=$ duty ratio/frequency

$$
\mathrm{C}=\text { Iout } * \mathrm{D} /(\mathrm{F} * \mathrm{dV})
$$

Table 1. Simulation parameters of KY converter

\begin{tabular}{|l|l|}
\hline Parameter & Value \\
\hline Vin & $12 \mathrm{~V}$ \\
\hline Frequency & $1 \mathrm{KHz}$ \\
\hline Inductor(L) & $1.8 \mathrm{e}-5 \mathrm{H}$ \\
\hline Capacitor $(\mathrm{Cb})$ & $1.7 \mathrm{e}-3 \mathrm{~F}$ \\
\hline Capacitor(C) & $1 \mathrm{~F}$ \\
\hline Duty cycle & $50 \%$ \\
\hline R Load & $300 \mathrm{Ohm}$ \\
\hline
\end{tabular}


R.Elavarasu et al., International Journal of Emerging Trends in Engineering Research, 8(10), October 2020,7116 - 7121

\subsection{LUO Converter}

The circuit diagram of the Luo converter is shown in Fig 4. In this circuit, two switches are used. One is the controllable switch (Power MOSFET) and the other is an uncontrollable switch (Diode). The diode is used as a freewheeling diode. The passive energy storage elements L1, L2, C1, and C2 are used. Resistive load $\mathrm{R}$ is used in output. The operation of the Luo converter divided into two modes.

Mode 1: when switch ' $S$ ' is closed, the supply voltage $V_{\text {in }}$ appears across the inductor and it is getting charged. The capacitor $\mathrm{C}_{1}$ and inductor $\mathrm{L}_{2}$ are connected in series and start discharging. The capacitor energy $C_{1}$ is transferred to the resistive load $\mathrm{R}$ through $\mathrm{L}_{2}$. Hence the current in the inductor increases until the switch ' $\mathrm{S}$ ' is off condition.

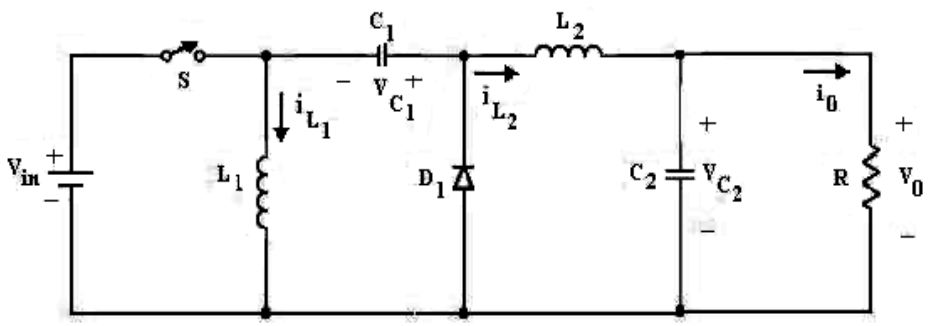

Fig 4. Circuit diagram of Luo converter

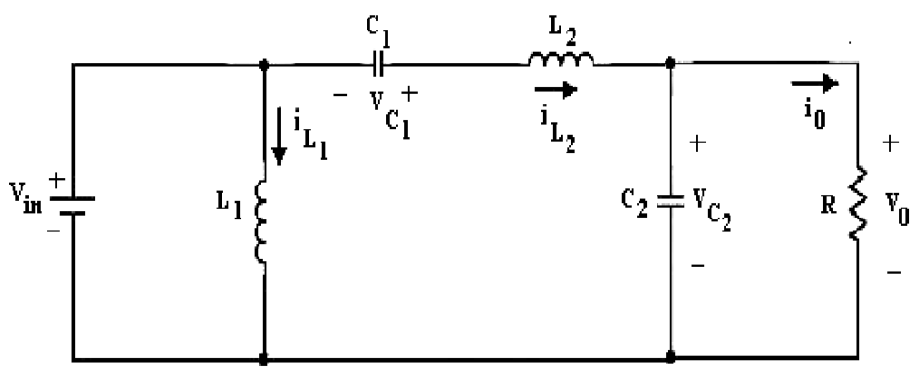

Fig 5. Operation of LUO converter in Mode 1

Mode 2: When the switch ' $\mathrm{S}$ ' is open, the supply is disconnected from the load. The inductor current $i_{L 1}$ flows through freewheeling diode $\mathrm{D}_{1}$ and it will charge the capacitor $\mathrm{C}_{1}$. The inductor current $\mathrm{i}_{\mathrm{L} 2}$ flows through the capacitor $\mathrm{C}_{2}$ and resistor load $\mathrm{R}$ and freewheeling diode $\mathrm{D}_{1}$. This makes the circuit in continuous conduction mode.

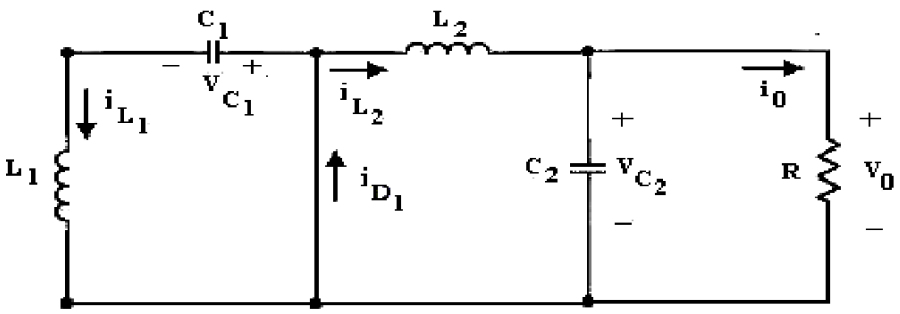

Fig 6. Operation of LUO converter in Mode 2
The average output voltage is calculated as

$$
\text { Vout }=\mathrm{D} / 1-\mathrm{D} * \mathrm{Vi} / \mathrm{p}
$$

The average output current is calculated as

$$
\text { Iout }=\mathrm{D} / 1-\mathrm{D} * \mathrm{Ii} / \mathrm{p}
$$

The voltage gain of the converter is calculated as

$$
\text { Vout } / \mathrm{Vi} / \mathrm{p}=\mathrm{D} / 1-\mathrm{D}
$$

The inductor current $\mathrm{I}_{\mathrm{L} 2}$ calculated as

$$
\mathrm{I}_{\mathrm{L} 2}=1-\mathrm{D} / \mathrm{D} * \mathrm{I}_{\mathrm{L} 1}
$$

Duty cycle

$$
\mathrm{D}=\mathrm{Ton} / \mathrm{T}
$$

Where $\mathrm{T}$ is total time

Average voltage across the inductor is

$$
\mathrm{V}_{\mathrm{cl}}=\mathrm{D} / 1-\mathrm{D} * \mathrm{Vi} / \mathrm{p}
$$

Peak to peak inductor current L1 is ,

$$
\nabla \mathrm{I}_{\mathrm{L} 1}=\mathrm{DTVi} / \mathrm{p} / \mathrm{L} 1
$$

Inductor L1 is calculated as

$$
\mathrm{L} 1=\mathrm{DTVi} / \mathrm{p} / \nabla \mathrm{I}_{\mathrm{L} 1}
$$

Peak to peak inductor current L2 is,

$$
\nabla \mathrm{I}_{\mathrm{L} 2}=\mathrm{DTVi} / \mathrm{p} / \mathrm{L} 2
$$

Inductor L1 is calculated as

$$
\mathrm{L} 2=\mathrm{DTVi} / \mathrm{p} / \nabla \mathrm{I}_{\mathrm{L} 2}
$$

Peak to peak ripple voltage across the capacitor $\mathrm{C} 1$ is ,

$$
\nabla \mathrm{V}_{\mathrm{C} 1}=1-\mathrm{D} \mathrm{TI}_{\mathrm{L} 1} / \mathrm{C} 1
$$

Capacitor $\mathrm{C} 1$ is calculated as

$$
\mathrm{C} 1=1-\mathrm{DT} \mathrm{I}_{\mathrm{L} 1} / \nabla \mathrm{V}_{\mathrm{C} 1}
$$

Table 2. Simulation parameters of LUO converter

\begin{tabular}{|l|l|}
\hline Parameter & Value \\
\hline Vin & $12 \mathrm{~V}$ \\
\hline Frequency & $1 \mathrm{KHz}$ \\
\hline Inductor(L1) & $100 \mu \mathrm{H}$ \\
\hline Inductor(L2) & $100 \mu \mathrm{H}$ \\
\hline Capacitor (C1) & $10 \mu \mathrm{F}$ \\
\hline Capacitor(C2) & $10 \mu \mathrm{F}$ \\
\hline Duty cycle & $50 \%$ \\
\hline R Load & $300 \mathrm{Ohm}$ \\
\hline
\end{tabular}


R.Elavarasu et al., International Journal of Emerging Trends in Engineering Research, 8(10), October 2020, 7116 - 7121

\section{SIMULATION CIRCUIT AND RESULTS}

The simulation circuit for KY and Luo converter is shown in Fig.7. The simulation circuit of KY and Luo converter is designed using MATLAB/Simulink. In this circuit, the input source is used as a controlled voltage source instead of using a $\mathrm{PV}$ panel. The input voltage range is from $10 \mathrm{~V}$ to $15 \mathrm{~V}$, the frequency is $1 \mathrm{kHz}$ and the duty cycle is $50 \%$ for both the converters. The input voltage disturbance is given to both the converter at the same time and the performance analyses are observed from the output waveforms.

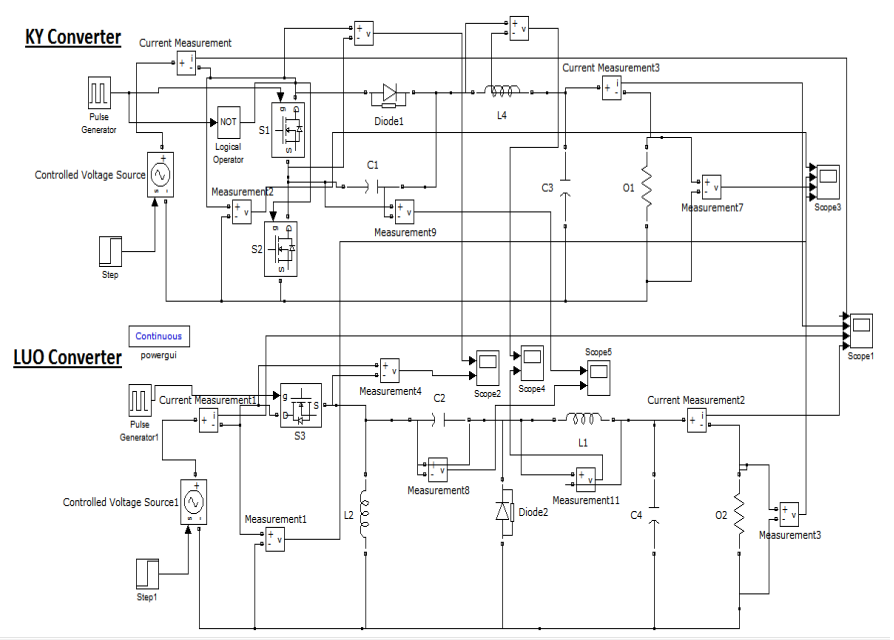

Fig 7. Simulation circuit of KY and LUO converter

The KY and Luo converters are working under continuous conduction mode (CCM). The input voltage waveform of KY and Luo converter is shown in fig. 9. The initial voltage is given as $12 \mathrm{~V}$ for both $\mathrm{KY}$ and Luo converter through controlled voltage source for $8 \mathrm{sec}$. The output voltage of KY and Luo converters are $25 \mathrm{~V}$ and $42 \mathrm{~V}$ respectively. From the output waveforms of KY and Luo converters its observed that, the rise time of Luo converter very less with compared to KY converter. Now the disturbance in the input voltage is given to both converter at the same time. The output voltage of KY and Luo converters are increased to $33 \mathrm{~V}$ and $55 \mathrm{~V}$ respectively. From the output waveforms its observed that, for any changes in the input voltage, the Luo converter is responding very quickly with compared with KY converter. Also the voltage stress across the switches are very less with compared to KY converter is shown in fig.8.
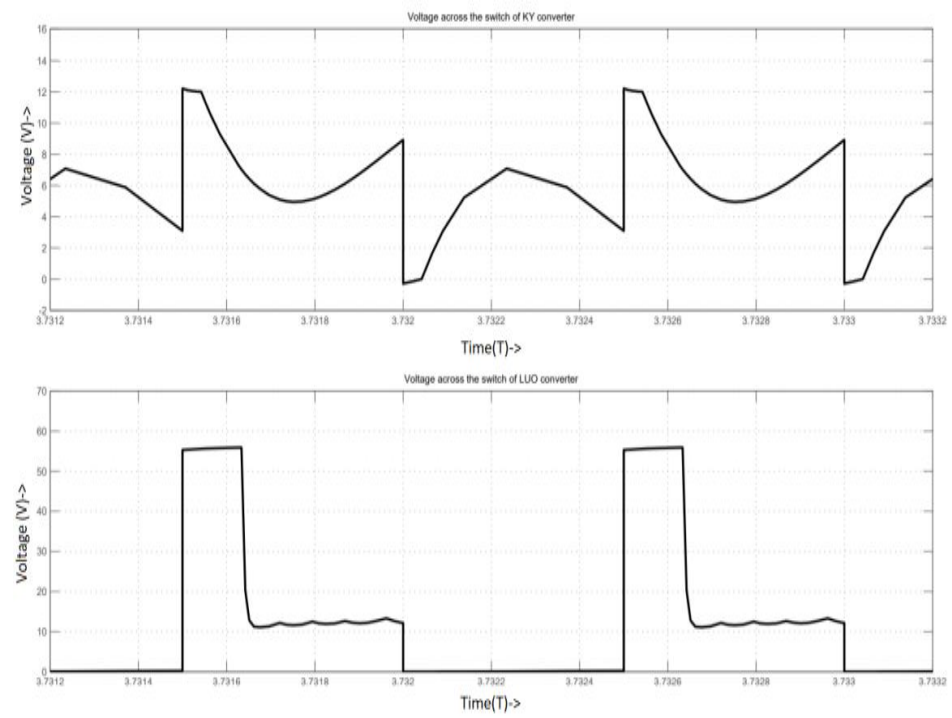

Fig 8. Voltage across the switch of KY and Luo converter
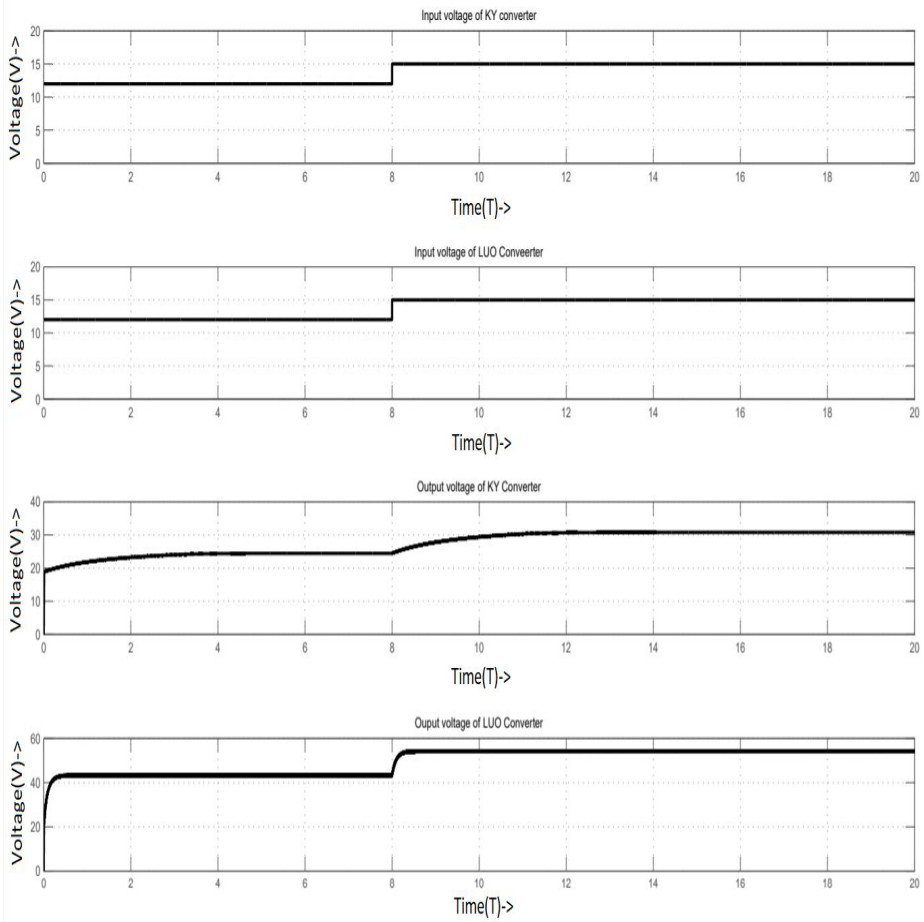

Fig 9. Input voltage and output voltage waveforms of KY and LUO converter

The input current and out current waveform of KY and Luo converter is shown in Fig.10 and Fig.11. The KY and Luo converter output currents are $0.08 \mathrm{~A}$ and $0.15 \mathrm{~A}$ respectively for the input voltages of $12 \mathrm{~V}$ for both the converter. The output current value is increased to $0.1 \mathrm{~A}$ and $0.18 \mathrm{~A}$ for the sudden changes of $12 \mathrm{~V}$ to $15 \mathrm{~V}$. From the output current waveforms of fig. 10 and fig. 11 , its observed that the rise time 
R.Elavarasu et al., International Journal of Emerging Trends in Engineering Research, 8(10), October 2020, 7116 - 7121

of Luo converter is very less with compared to KY converter also the ripple current is very less in Luo converter.
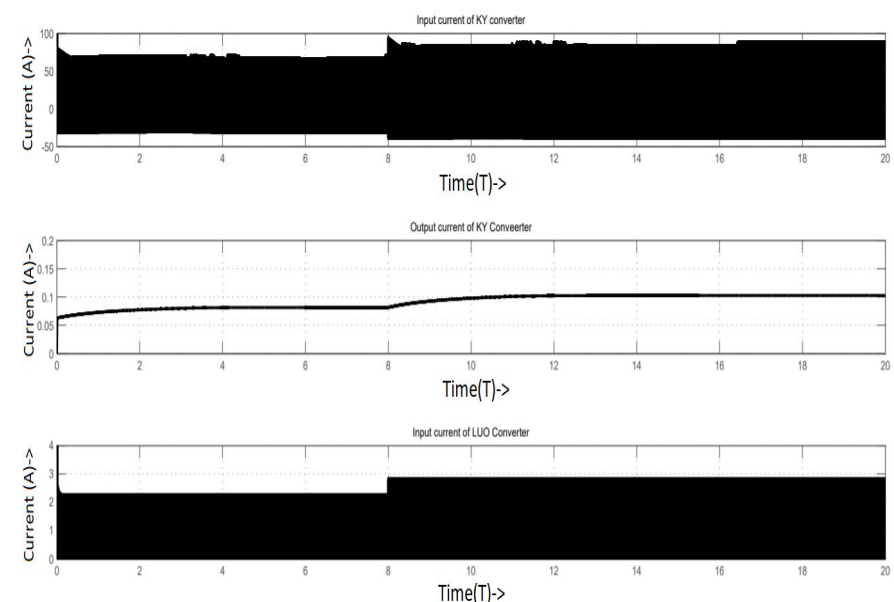

Time(T)->

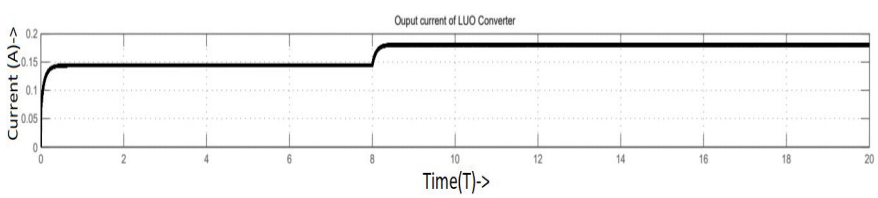

Fig 10. Input current and output current waveforms of KY and LUO converter
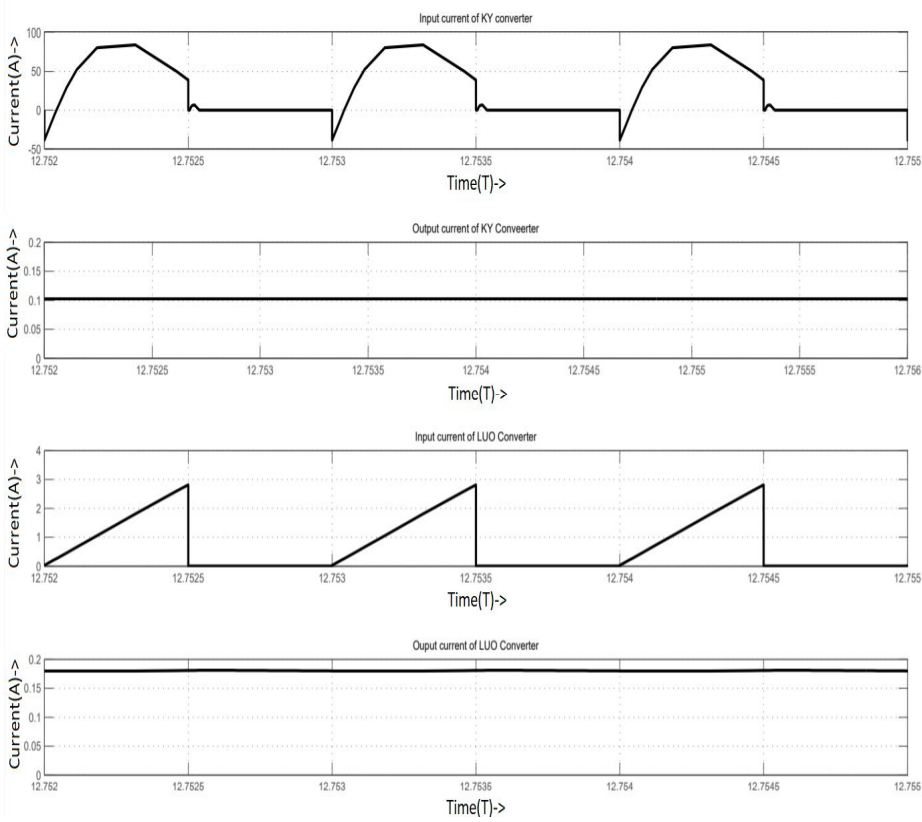

Fig 11. Input current and output current waveforms of KY and LUO converter (zoom view)
The performance parameters of KY and Luo converters are tabulated below.

Table 3. Comparison of parameters from waveforms of KY and LUO converter

\begin{tabular}{|l|l|l|}
\hline Parameters & KY Converter & LUO Converter \\
\hline Input voltage & $12-15 \mathrm{~V}$ & $12-15 \mathrm{~V}$ \\
\hline Output voltage & $25-35 \mathrm{~V}$ & $45-55 \mathrm{~V}$ \\
\hline Output current & $0.05-0.1 \mathrm{~A}$ & $0.15-0.18 \mathrm{~A}$ \\
\hline Transient response & $4 \mathrm{Sec}$ & $0.3 \mathrm{Sec}$ \\
\hline Gain & 2.08 & 3.75 \\
\hline
\end{tabular}

\section{CONCLUSION}

The Luo and KY converters are modeled and simulated using MATLAB/Simulink. The simulation has been performed for the same input voltage of both the converters with the same frequency and duty cycle of 50\%. The input disturbance is applied simultaneously to both the converter and the performances are analyzed and the parameters are tabulated for the above converters. The results are observed from input and output voltage and current waveforms. The voltage stresses across the switches and ripple current waveform also observed. From the waveforms and tabulations, it's concluded that the Luo converter is performed better while the disturbance is applied and the gain of the Luo converter also better than the KY converter. From the above observations, it's concluded that Luo converter is suited for renewable energy sources.

\section{REFERENCES}

1. B. M. Hasaneen, Adel A. Elbaset Mohammed : Design and simulation of DC/DC boost converter, 12th International Middle-East Power System Conference, (2008).

2. S. Masri, P. W. Chan: Design and development of a DC-DC boost converter with constant output voltage, International Conference on Intelligent and Advanced Systems, (2010).

3. Ying Zhang, Dan Li,Hao Lu, Shiquan Fan,Zeqiang Chen, Yan Wang, and Li Geng : Analysis and Implementation of High-Performance Integrated KY Converter, IEEE Transactions on Power Electronics, (2017)

4. R.Elavarasu, Aushwin Kumar S, Anjan Srinivas S, P.Shanmugapriya, Fazal Mohamed J. Analysis of Variable Speed Micro Wind Energy Generator Using SEPIC Converter, International Journal of Emerging Trends in Engineering Research (IJETER), Vol.8. No.4 April 2020. 
5. K. I. Hwu and Y. T. Yau : KY converter and its derivatives, IEEE Trans.Power Electron., 24(1), pp. 128-137, 2009.

6. Meera $\mathrm{R}$ Nair, Ms. Priya Jose : Voltage Gain Enhancement Using Ky Converter, IOSR Journal of Electrical and Electronics Engineering (IOSR-JEEE), pp. 27-34, (2017).

7. Sundararaman K, Elavarasu R, Bindu K V. A Soft-Switched Bi-directional DC-DC Converter for a BLDC motor based Electric Vehicle. International Journal of Emerging Trends in Engineering Research, Volume 8. No. 6, June 2020.

8. He, Y., \& Luo, F. L. : Analysis of Luo converters with voltage-lift circuit, IEEE Proceedings-Electric Power Applications, 152(5), pp. 1239-1252, (2005).

9. Luo, F. L., and Ye, H. : Advanced dc/dc converters, crc Press, (2016).

10. Wentao Jiang, et al. : Improved output feedback controller design for the super-lift re-lift Luoconverter, IET Power Electronics, 10(10),pp. 1147 1155, (2017).

11. Thrishna Jayaraj, G.Justin Sunil Dhas : KY Based DC-DC Converter for Standalone Photovoltaic Water Pumping System Employing Four Switch BLDC Drive, ICEES 2019 Fifth International Conference on Electrical Energy Systems, 21- 22 February 2019, SSN College of Engineering, Chennai, India.

12. Ying Zhang, Dan Li, Hao Lu, Shiquan Fan, Zeqiang Chen, Yan Wang, Li Geng,: Analysis and Implementation of a High-Performance-Integrated KY Converter. IEEE Transactions on Power Electronics. 32(12), (2017)

13. Wen-Liang Zeng, Chi-Wa U, Chi-Seng Lam,: Review and Comparison of Integrated Inductive-Based Hybrid Step-Up DC-DC Converter under CCM. IEEE 62nd International Midwest Symposium on Circuits and Systems 2016 (MWSCAS) 4-7 Aug. 2019. 